\title{
In vitro anticancer property of Solanum mammosum callus culture against HeLa and Vero cell lines
}

\author{
SUCIATI $^{1 *}\left(\mathbb{D}\right.$, Lusiana ARIFIANTI ${ }^{1}(\mathbb{D})$, Andiena ELSAFIRA ${ }^{1}\left(\mathbb{D}\right.$, Lovely $^{\text {Q. ILMIAH }}{ }^{1}$ (D) \\ 1 Department of Pharmacognosy and Phytochemistry, Faculty of Pharmacy, Universitas Airlangga, Surabaya 60115, \\ Indonesia. \\ * Corresponding Author. E-mail: suciati@ff.unair.ac.id (S.); Tel. +62-31-593 3150.
}

Received: 08 November 2019 / Revised: 20 February 2020/ Accepted: 20 February 2020

\begin{abstract}
Breast cancer and cervical cancer were ranked first and fourth of the leading cause of death of women in the world. One of natural compounds that was reported on having cytotoxic activity against various cancer cells with high selectivity is betulinic acid. In our previous study, it was found that the acetone extract of Solanum mammosum callus culture contains betulinic acid. The aims of the current study were firstly to investigate the anticancer activity of the acetone extract of S. mammosum as well as betulinic acid, and secondly to quantitatively determine the betulinic acid content in the acetone extract of $S$. mammosum culture. The anticancer activity was carried out using the MTT method against HeLa and Vero cells. The determination of betulinic acid content was done using the TLC densitometry method. The results showed that the acetone extract of $S$. mammosum gave anticancer activity against HeLa cancer cells with $\mathrm{IC}_{50}$ value of $120.5 \mu \mathrm{g} / \mathrm{mL}$, however, it was less active compared to betulinic acid with $\mathrm{IC}_{50}$ of $19.3 \mu \mathrm{g} / \mathrm{mL}$. Both samples were found to be non-toxic on Vero normal cells. Based on TLC densitometry, the acetone extract of $S$. mammosum contain $1.2 \% \mathrm{w} / \mathrm{w}$ betulinic acid.
\end{abstract}

KEYWORDS: Solanum mammosum; callus culture; anticancer; HeLa; Vero, betulinic acid.

\section{INTRODUCTION}

Cancer has been considered as the second leading cause of death after cardiovascular disease. According to data from the International Agency for Research on Cancer (IARC), there were 18.1 million new cases and 9.6 million cancer deaths that occurred in 2018 globally. It is projected that in 2040, the incidence of cancer will rise to 29.5 million new cases [1]. This increasing number is the result of various factors, such as genetics, exposure to carcinogenic substances (radiation and chemicals), as well as an unhealthy lifestyle.

Common therapy for cancer includes, chemotherapy, surgery, and radiation. Chemotherapy has been widely used to cure cancer, which involves the use of chemotherapeutic agents, such as 5-fluorouracil, doxorubicin, bleomycin, and cyclophosphamide. However, many chemotherapeutic agents are not specific, it not only kill the cancer cells but also inhibits normal cells. Mild to severe side effects have also been reported. The use of 5-fluorouracil and doxorubicin can cause cardiotoxicity and myelotoxicity, while bleomycin causes pulmonary and cutaneous toxicity. The incidence of bladder toxicity, as well as cardiotoxicity, have also been reported due to the use of cyclophosphamide. Therefore, current anticancer research is focused on finding therapeutic agents with selective cytotoxicity and minimal side effects. The anticancer property of plant has been well known, example includes the alkaloid compounds, vincristine, and vinblastine, which derived from Catharathus roseus $[2,3]$.

The cell cultures of plants from the genus Solanum have been reported to contain various metabolites, such as sterols and triterpenes [4-8]. In our previous study, we have reported the presence of betulinic acid in the callus culture of Solanum mammosum; this compound only present in the compact globular structure callus of S. mammosum [9]. The present of betulinic acid was firstly reported from the bark of Betula sp., but it was later also found in the in vitro culture of Solanum aviculare [10], Paeonia japonica [11], Glycyrrhiza glabra [12], Lantana camara [13], and Cyclocarya paliurus [14]. The callus culture of S. aviculare reported containing 3\% betulinic acid. The amount of betulinic acid in the in vitro culture of $S$. mammosum has not been reported.

Currently, betulinic acid has attracted attention due to its potent bioactivities [15-19], including as anticancer. This triterpene compound has been reported to have anticancer property against various cancer

How to cite this article: Suciati, Arifianti L, Elsafira A, Ilmiah LQ. In vitro anticancer property of Solanum mammosum callus culture against HeLa and Vero cell lines. J Res Pharm. 2020; 24(2): 218-224. 
cell lines [20-23]. Therefore, the aim of the current study is to investigate the anticancer property of $S$. mammosum as well as betulinic acid against HeLa cervical cancer cell line. Quantitative determination of betulinic acid in the extract was also conducted.

\section{RESULTS AND DISCUSSION}

\subsection{Anticancer assay}

The anticancer properties of the acetone extract of Solanum mammosum callus culture and betulinic acid were determined by MTT assay. This assay was chosen since it is reliable, simple, applicable to a wide range of cells, and can be performed in microtitre plates. The assay was based on the colorimetric reaction of 3-(4,5dimethylthiazol-2-yl)-2,5-diphenyltetrazolium bromide with dehydrogenase enzyme inside living cells to form a colored formazan dye, which corresponded to the number of viable cells [24].

In this study, the anticancer activity of betulinic acid and the acetone extract of S. mammosum callus culture were examined against human cervix carcinoma cell (HeLa) and normal cell (Vero). The results presented in Figures 1-2 and Table 1 demonstrated that both betulinic acid and the acetone extract of $S$. mammosum callus culture inhibited the growth of HeLa cells, however, betulinic acid showed stronger cytotoxic activity compared to the $S$. mammosum callus extract with $\mathrm{IC}_{50}$ values of 19.3 and $120.5 \mu \mathrm{g} / \mathrm{mL}$, respectively. In order to examine the selectivity and the safety of both extract and betulinic acid, inhibition against normal cell Vero was also conducted. The results presented in Figure 2 showed that at concentration up to $500 \mu \mathrm{g} / \mathrm{mL}$, both samples gave more than $60 \%$ cell viability, which indicates that the sample is safe for normal cells. The selectivity index (SI) of the samples were then calculated, and obtain SI values of $>25.9$ and $>4.1$ for betulinic acid and the acetone extract of S. mammosum callus, respectively. The SI value of $>2$, indicates that both samples are selective against HeLa cancer cell line [25]. These findings are in agreement with previous reports on the activity of betulinic acid against HeLa cancer line. Betulinic acid isolated from various sources was found as a potent anticancer agent against HeLa [26,27]. Xu et al. suggested that this compound can induce apoptosis in HeLa cell through downregulating of PI3K/ Akt signaling and mitochondrial pathway [28].

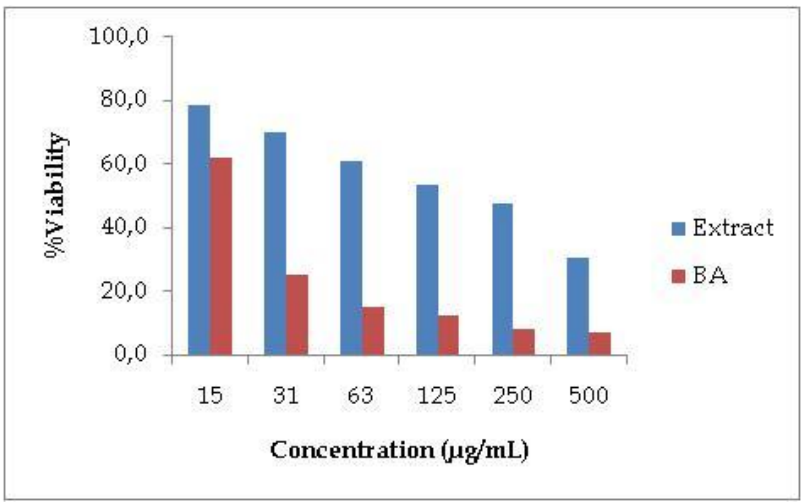

Figure 1. Effect of S. mammosum callus extract and betulinic acid (BA) on cell viability in HeLa cells.

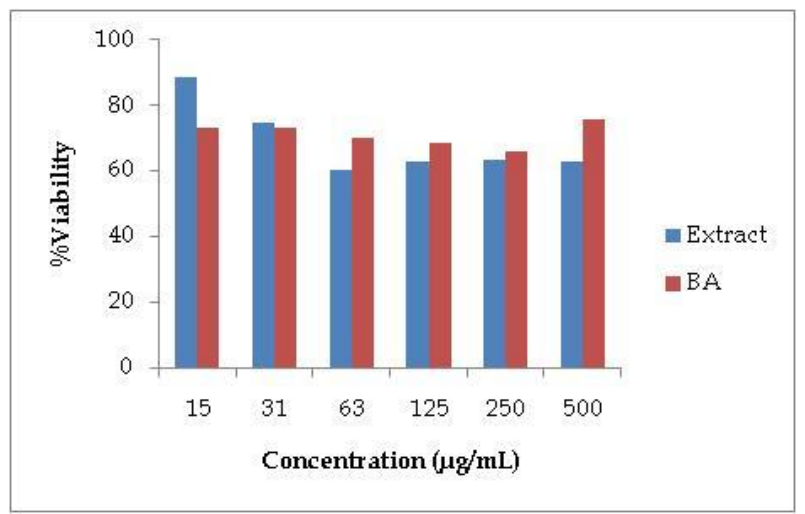

Figure 2. Effect of S. mammosum callus extract and betulinic acid (BA) on cell viability in Vero cells. 
Table 1. $\mathrm{IC}_{50}$ values of samples against HeLa and Vero cell lines.

\begin{tabular}{cccc}
\hline Samples & \multicolumn{2}{c}{$\mathrm{IC}_{50}$ values $(\mu \mathrm{g} / \mathrm{mL})$} & \multirow{2}{*}{ SI value } \\
\cline { 2 - 3 } & HeLa & Vero & \\
\hline Acetone extract of S. mammosum callus & $120.5 \pm 4.7$ & $>500$ & $>4.1$ \\
Betulinic acid & $19.3 \pm 3.6$ & $>500$ & $>25.9$ \\
\hline
\end{tabular}

Values were expressed as mean $\pm \mathrm{SD}$, experiments were done in triplicates

Selectivity Index (SI) : $\mathrm{IC}_{50}$ against Vero cell/ $\mathrm{IC}_{50}$ against HeLa cell

\subsection{Quantitative determination of betulinic acid in $S$. mammosum callus culture}

The amount of betulinic acid in the acetone extract of S.mammosum callus was determined by TLC densitometry according to the modified method of Murthy and Mishra (2008) as well as Mukherjee et al. (2010) $[29,30]$. Samples were applied on to TLC plate and developed with a combination of $n$-hexane : ethyl acetate : acetic acid (7:3:0.3); followed by derivatization with anisaldehyde-sulphuric acid, and the TLC plate was heated at $110^{\circ} \mathrm{C}$ for 10 mins. A purplish red spot will appear against a white background, corresponding to the presence of terpenoid compound, which in this case betulinic acid. Further visualization was performed at $540 \mathrm{~nm}$. The thin-layer chromatograms of the acetone extract of S. mammosum callus and the standard betulinic acid are shown in Figure 3. A single peak at Rf 0.4 min was observed in the chromatogram of standard betulinic acid. A peak appeared at the same Rf as in standard was also observed in the acetone extract of $S$. mammosum callus.
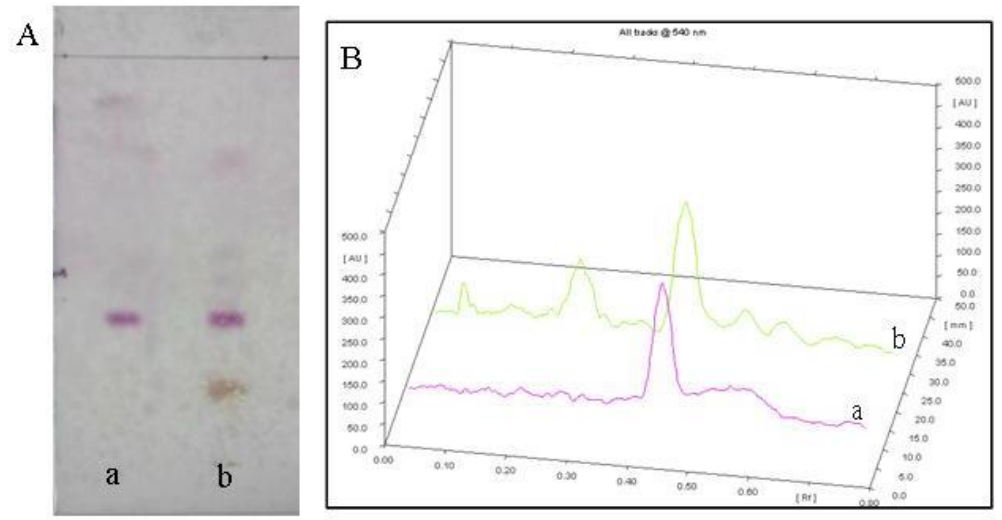

Figure 3. TLC profile (A) and three dimensional chromatogram (B) of standard betulinic acid (a) and $S$. mammosum callus extract (b).

In order to determine the amount of betulinic acid in the S. mammosum callus, a calibration curve was plotted by applying serial concentrations of betulinic acid ranging from 0.4 to $4 \mu \mathrm{g}$ on the TLC plate. The correlation coefficient $(r)$ value obtained was 0.99176 , which suggested good linearity. The calibration curve was plotted and the linear equation $y=3847.86 x+1673.65$ obtained, as can be seen in Table 2 . Based on this equation the amount of betulinic acid was calculated, and it was found that the $1.2 \%(\mathrm{w} / \mathrm{w})$ betulinic acid present in the acetone extract of $S$. mammosum or equivalent to $0.76 \%(\mathrm{w} / \mathrm{w})$ in the dried callus.

To further confirm the results, validation of the method was carried out, by determining specificity, linearity, and accuracy. The specificity of the method was shown from the peak corresponded to betulinic acid in the extract that did not interfere with other peaks in the extract. The specificity of the method was confirmed form the value of similarity index (SI) based on the comparison of UV spectra of standard betulinic acid to the peak at the same Rf value in the extract, which shown SI value of 0.98663 (Figure 4). The peak purity of betulinic acid in the extract was assessed by comparing the spectra at three different levels, i.e. peak start, peak middle and peak end positions of the spot, the value represented as $r(s, m)$ and $r(m, e)$. Based on the measurement, the $r(\mathrm{~s}, \mathrm{~m})$ and $\mathrm{r}(\mathrm{m}, \mathrm{e})$ values obtained were $>0.999$, which suggested that the purity is good [31]. The linearity was confirmed by applying six different concentrations of standard solutions of betulinic acid, the results can be seen in Table 2 indicated a good linear relationship between the concentrations of samples and peak areas. The accuracy (recovery) study was performed by the method of standard addition. Standard betulinic acid was added to the samples at three different levels, $30 \%, 50 \%$ and $70 \%$. The percentage 
recovery of betulinic acid in the extract was found to be $99.92 \%$ (Table 2). This \% recovery value was in accordance with the requirement that the \% recovery should be $95-105 \%$ [31].

Table 2. Quantitative and validation data of betulinic acid.

\begin{tabular}{lcc}
\hline & Parameter & Results \\
\hline \multirow{3}{*}{ Linearity } & $\mathrm{Rf}$ & 0.40 \\
& Range of standards $(\mu \mathrm{g} / \mathrm{spot})$ & $0.4-4 \mu \mathrm{g}$ \\
& Equation & $\mathrm{Y}=3847.86 \mathrm{x}+1673.65$ \\
& Linearity (correlation coefficient) & 0.99176 \\
Specificity & Similarity index $(\mathrm{SI})$ & 0.98663 \\
& $\mathrm{R}(\mathrm{s}, \mathrm{m})$ & 0.999477 \\
\multirow{3}{*}{ Accuracy } & $\mathrm{R}(\mathrm{m}, \mathrm{e})$ & 0.999849 \\
& $\%$ recovery & $98.43-101.14 \%$, average: \\
& & $99.92 \%$ \\
& Concentration of betulinic acid in extract & $1.2 \%(\mathrm{w} / \mathrm{w})$ \\
\hline
\end{tabular}

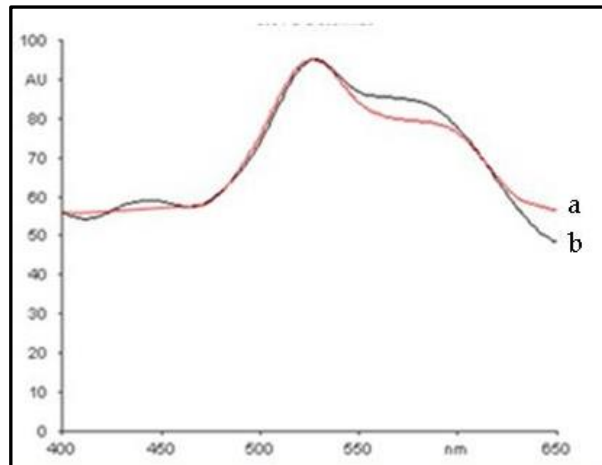

Figure 4. Overlaid UV spectra of standard betulinic acid (a) and extract of S. mammosum callus (b) at Rf 0.40.

The presence of betulinic acid in several plant callus cultures has been reported [10-14]. In this study the quantitative determination of betulinic acid was carried out on the acetone extract since our previous investigation suggested that this compound only presence in the acetone extract [9]. It is found that the acetone extract contain $1.2 \%(\mathrm{w} / \mathrm{w})$ of betulinic acid equivalent to $0.76 \%(\mathrm{w} / \mathrm{w})$ dry callus. This amount is lower compared to the amount of betulinic acid in the callus of Solanum aviculare [10]. Modification of growth media or other techniques, such as elicitation with methyl jasmonate can be an alternative to increase the amount of betulinic acid in the callus culture of S. mammosum [32].

\section{CONCLUSION}

The acetone extract of $S$. mammosum callus and betulinic acid showed cytotoxic activity against HeLa cell, but low cytotoxic activity against Vero cell. The acetone extract of S. mammosum contains $1.2 \%(\mathrm{w} / \mathrm{w})$ betulinic acid. This compound may be responsible for the anticancer property of $S$. mammosum callus extract.

\section{MATERIALS AND METHODS}

\subsection{Preparation of callus cultures}

Callus cultures of $S$. mammosum were grown in $300 \mathrm{~mL}$ Erlenmeyer containing $50 \mathrm{~mL}$ medium (modified Murashige-Skoog medium, supplemented with $7 \mathrm{~g} / \mathrm{L}$ Agar, sucrose $30 \mathrm{~g} / \mathrm{L}, 2 \mathrm{mg} / \mathrm{L}$ kinetin and $0.5 \mathrm{mg} / \mathrm{L}$ 1Naphtaleneacetic acid) at $25 \pm 2^{\circ} \mathrm{C}$ under continuous light (ca 2000 lux). The cultures were sub-cultured every 4 weeks of incubation, as described in our previous work [9].

\subsection{Sample preparation}

Extraction was carried out according to the previous published method [9]. Oven dried $\left(40^{\circ} \mathrm{C} ;\right.$ moisture content $4.9 \%$ ) powdered callus $(10 \mathrm{~g})$ was extracted with $100 \mathrm{~mL} n$-hexane by ultrasonication $(3 \times 15 \mathrm{~min})$. The extract and the residue were separated by filtration. The residue was further extracted with acetone $(100 \mathrm{~mL})$ 
using the same procedure. The acetone extract was evaporated to dryness under vacuo to obtain a crude acetone extract $(0.657 \mathrm{~g})$.

\subsection{In vitro cytotoxicity assay}

A modification of the method described by Freshny (2010) was used [33]. HeLa cells were cultured in RPMI 1640 and Vero cells were cultured in M199 medium. Both media supplemented with fetal bovine serum $10 \%$ and penicillin-streptomycin $1 \%(\mathrm{v} / \mathrm{v})$. Cells $\left(5 \times 10^{3}\right.$ cells/wells) were transferred to 96 well plate and incubated for $24 \mathrm{~h}$ in $37^{\circ} \mathrm{C}, 5 \% \mathrm{CO}_{2}(70-80 \%$ confluent). Tested samples were dissolved in DMSO and further diluted with media to make series of concentrations $(7.5-500 \mu \mathrm{g} / \mathrm{mL})$. The final concentration of DMSO in the test solution should not more than $1 \%$. Control cell was treated with $1 \%$ DMSO. Cells were then treated with a serial dilution of tested samples. After $24 \mathrm{~h}$ of incubation, MTT [3-(4,5-dimethylthiazol-2-yl)2-5diphenyl tetrazolium bromide] $0.5 \mathrm{mg} / \mathrm{ml}$ were added to each wells, followed by incubation for $4 \mathrm{~h}$. A solution of sodium dodecylsulfate $(10 \%)$ in $0.1 \mathrm{~N} \mathrm{HCl}$ was added to dissolve formazan crystal. Cells were further incubated overnight at room temperature and protected from light. Reaction mixtures were homogenized by shaking for $0.5 \mathrm{~min}$ before measurement of absorbance using ELISA reader at $\lambda 595 \mathrm{~nm}$. The percentage of cell viability was calculated by using the equation below (Equation 1 ) and the $\mathrm{IC}_{50}$ values were determined by Probit analysis using SPSS software. Experiments were done in triplicates.

$$
\% \text { Viability }=\left(\frac{\text { absorbance of sample-absorbance of control media }}{\text { absorbance of control cell-absorbance of control media }}\right) \times 100 \%
$$

\subsection{Quantitication of betulinic acid}

\subsubsection{Preparation of extracts and standard}

Dried callus $(200 \mathrm{mg})$ was extracted with $2.5 \mathrm{~mL} n$-hexane by ultrasonication $(3 \times 15 \mathrm{~min})$. The extract was filtered and the residue was re-extracted by using the same procedure with $2.5 \mathrm{~mL}$ acetone. Each extraction was repeated 3 times. The collected acetone extract was then evaporated to dryness under vacuo. Two separated extractions were carried out for the callus. Each extract was then dissolved in $2 \mathrm{~mL}$ of methanol. Standard betulinic acid (Sigma 855057) was dissolved in methanol to obtain a stock solution at $1000 \mu \mathrm{g} / \mathrm{mL}$, which was further serial diluted with methanol to make concentrations $100,200,300,400$, and $500 \mu \mathrm{g} / \mathrm{mL}$.

\subsubsection{TLC analysis}

Chromatography was performed on a pre-coated TLC plate, silica gel 60F $254(10 \mathrm{~cm} \times 20 \mathrm{~cm})$. Samples and standards were applied to the plate as $7 \mathrm{~mm}$ bands with a Camag automatic TLC sampler (Linomat 5) spray-on band applicator equipped with $100 \mu \mathrm{L}$ syringe, and the space between two spots was $15 \mathrm{~mm}$ of the plate. Six concentrations of standards were applied on the TLC plates, $4 \mu \mathrm{L}$ each to obtain different amount of standards $(0.4-4 \mu \mathrm{g} / \mathrm{spot})$. Samples prepared from two extractions were each applied duplicates on the plate $(4 \mu \mathrm{L})$.

The TLC plates were developed with mobile phase $n$-hexane:ethyl acetate:acetic acid (7:3:0.03 v/v). TLC plates were then air dried, and derivatization was undertaken by spraying anisaldehyde $-\mathrm{H}_{2} \mathrm{SO}_{4}$ reagent, followed by heating in the oven at $110^{\circ} \mathrm{C}$ for 10 mins. The densitometric scanning was performed at $540 \mathrm{~nm}$ with a Camag TLC scanner 3 equipped with WinCATS software, using a deuterium light source; the slit dimension was $6.00 \times 0.45 \mathrm{~mm}$. Peak areas were recorded, and the amount of betulinic acid was calculated using the calibration plot. The specificity of the method was determined by analyzing UV spectra of the standard betulinic acid and the unknown sample. The spot for betulinic acid in the sample was confirmed by comparing the RF and spectra of the spot with that of the standard. The peak purity of betulinic acid was assessed by comparing the spectra at three different levels, i.e. peak start, peak apex, and peak end positions of the spot. The accuracy was determined by standard addition method, with three levels of standard addition, $30 \%, 50 \%$ and $70 \%$. 
Acknowledgements: Authors acknowledge Faculty of Pharmacy, Universitas Airlangga for BOPTN research grant.

Author contributions: Concept - S.; Design - S., L.A.; Supervision -S., L.A.; Resources - S; Materials - S.; Data Collection and/or Processing - A.E., L.I.; Analysis and/or Interpretation - S., L.A, A.E., L.I.; Literature Search - S., L.A, A.E., L.I.; Writing - S.; Critical Reviews - S., L.A, A.E., L.I.

Conflict of interest statement: The authors declared no conflict of interest.

\section{REFERENCES}

[1] Bray F, Ferlay J, Soerjomataram I, Siegel RL, Torre LA, Jemal A. Global cancer statistics 2018: GLOBOCAN Estimates of incidence and mortality worldwide for 36 cancers in 185 countries. CA Cancer J Clin. 2018; 68(6): 394-424. [CrossRef]

[2] Desai AG, Qazi GN, Ganju RK, El-Tamer M, Singh J, Saxena AK, Bedi YS, Taneja SC, Bhat HK. Medicinal plants and cancer chemoprevention. Curr Drug Metab. 2008; 9(7): 581-591. [CrossRef]

[3] Lichota A, Gwozdzinski K. Anticancer activity of natural compounds from plant and marine environment. Int J Mol Sci. 2018; 19(11): 3533. [CrossRef]

[4] Hosoda N, Yatazawa M. Sterols, steroidal sapogenin and steroidal alkaloid in callus culture of Solanum laciniatum ait. Agric Biol Chem. 1979; 43(4): 821-825. [CrossRef]

[5] Indrayanto G. PhD Thesis. Steroide und triterpene in zellkulturen: untersuchungen mit zellkulturen von Solanum laciniatum Ait., Solanum Wrightii Bth. und Costus speciosus (Koen) Sm. Universität Tübingen, Germany, 1983.

[6] Suardi ML, Bernasconi S, Pelizzoni F, Racchi ML. In vitro cultures of Solanum malacoxylon Sendt.: nutritional requirements and sterol production. Plant Cell Tissue Organ Cult. 1994; 36(1): 9-14. [CrossRef]

[7] Sutarjadi I, Indrayanto G. Sterols in callus cultures of Solanum mammosum. Planta Med. 1986; 52(5): 413. [CrossRef]

[8] Indrayanto G, Sondakh R, Utami W, Syahrani A. Solanum mammosum: in vitro cultures and the production of secondary metabolites. In: Bajaj YPS. (ed). Biotechnology in Agriculture and Forestry. vol. 41. Medicinal and Aromatic Plants. vol. X. Springer, Berlin, 1998, pp. 394-414.

[9] Juliana S, Suciati, Indrayanto G. Sterol and triterpene profiles of the callus culture of Solanum mammosum. Makara J Sci. 2019; 23(2): 72-78. [CrossRef]

[10] Vanek T, Macek T, Benes I, Novotny L. Occurrence of betulinic acid in different callus cultures of Solanum aviculare. Phytochemistry. 1985; 24(12): 3064-3065. [CrossRef]

[11] Ikuta A, Kamiya K, Satake T, Saiki Y. Triterpenoids from callus cultures of Paeonia species. Phytochemistry. 1995; 38(5): 1203-1207. [CrossRef]

[12] Hayashi H, Hiraoka N, Ikeshiro Y. Differential regulation of soyasaponin and betulinic acid production by yeast extract in cultured licorice cells. Plant Biotechnol. 2005; 22(3): 241-244. [CrossRef]

[13] Srivastava P, Kasoju N, Bora U, Chaturvedi R. Accumulation of betulinic, oleanolic and ursolic acids in in vitro cell cultures of Lantana camara L. and their significant cytotoxic effects on HeLa cell lines. Biotechnol Bioproc E. 2010; 15(6): 1038-1046. [CrossRef]

[14] Yin Z, Shangguan X, Chen J, Zhao Q, Li D.) Growth and triterpenic acid accumulation of Cyclocarya paliurus cell suspension cultures. Biotechnol Bioproc E. 2013; 18 (3): 606-614. [CrossRef]

[15] Dzubak P, HajduchM, Vydra D, HustovaA, Kvasnica M, Biedermann D, Markova L, Urban M, Sarek J. Pharmacological activities of natural triterpenoids and their therapeutic implications. Nat Prod Rep. 2006; 23(3):394411. [CrossRef]

[16] Chowdhury AR, Mandal S, Goswami A, Ghosh M, Mandal L, Chakraborty D, Ganguly A, Tripathi G, Mukhopadhyay S, Bandyopadhyay S, Majumderi H. Dihydrobetulinic acid induces apoptosis in Leishmania donovani by targeting DNA topoisomerase I and II: implications in antileishmanial therapy. Mol Med. 2003; 9(1-2): 26-36. [CrossRef]

[17] Santos RC, Salvador JAR, Marín S, Cascante M. Novel semisynthetic derivatives of betulin and betulinic acid with cytotoxic activity. Bioorg Med Chem. 2009; 7(17):6241-6250. [CrossRef]

[18] Liby K, Honda T, Williams CR, Risingsong R, Royce DB, Suh N, Dinkova-Kostova AT, Stephenson KK, Talalay P, Sundararajan C, Gribble GW, Sporn MB. Novel semisynthetic analogues of betulinic acid with diverse cytoprotective, antiproliferative and proapoptotic activities. Mol Cancer Ther. 2007; 6(7): 2113-2119. [CrossRef] 
[19] Puniani E, Cayer C, Kent P, Mullally M, Sánchez-Vindas P, Álvarez LP, Cal V,Merali Z, Arnason JT, Durst T. Ethnopharmacology of Souroubea sympetala and Souroubea gilgii (Marcgraviaceae) and identification of betulinic acid as an anxiolytic principle. Phytochemistry. 2015; 113: 73-78. [CrossRef]

[20] Cichewicz RH, Kouzi SA. Chemistry, biological activity and chemotherapeutic potential of betulinic acid for the prevention and treatment of cancer and HIV infection. Med Res Rev. 2004; 24(1): 90-114. [CrossRef]

[21] Fulda S, Jeremias I, Steiner HH, Pietsch T, Debatin KM. Betulinic acid: a new cytotoxic agent against malignant braintumor cells. Int J Cancer. 1999; 82(3): 435-441. [CrossRef]

[22] Laszczyk MN. Pentacyclic triterpenes of the lupane, oleanane and ursane group as tools in cancer therapy. Planta Med. 2009; 75(15): 1549-1560. [CrossRef]

[23] Periasamy G, Teketelew G, Gebrelibanos M, Sintayehu B, Gebrehiwot M, Karim A, Geremedhin G. Betulinic acid and its derivatives as anti-cancer agent: a review. Arch Appl Sci Res. 2014; 6(3): 47-58.

[24] McCauley J, Zivanovic A, Skropeta, D. Bioassays for anticancer activities. Methods Mol Biol. 2013; 1055: $191-205$. [CrossRef]

[25] Artun FT, Karagoz A, Ozcan G, Melikoglu G, Anil S, Kultur S, Sutlupinar N. In vitro anticancer and cytotoxic activities of some plant extracts on HeLa and Vero cell lines. J BIJON. 2016; 21(3): 720-725.

[26] Karan BN, Maity TK, Pal BC, Singha T, Jana S. Betulinic acid, the first lupane-type triterpenoid isolated via bioactivity-guided fractionation, and identified by spectroscopic analysis from leaves of Nyctanthes arbor-tristis: its potential biological activities in vitro assays. Nat Prod Res. 2019; 33(22): 3287-3292. [CrossRef]

[27] Khan MA, Ahamad T, Saquib M, Hussain MK, Khan MF. Unmodified household coffee maker assisted extraction and purification of anticancer agents from Dillenia indica fruits. Nat Prod Res. 2019; 28: 1-4. [CrossRef]

[28] Xu T, Pang Q, Wang Y, Yan X. Betulinic acid induces apoptosis by regulating PI3K/Akt signaling and mitochondrial pathways in human cervical cancer cells. Int J Mol Med. 2017; 40(6): 1669-1678. [CrossRef]

[29] Murthy K, Mishra S. TLC determination of betulinic acid from Nymphodies macrospermum: A new botanical source for tagara. Chroma. 2008; 68: 877-880. [CrossRef]

[30] Mukherjee D, Kumar NS, Khatua T, Mukherjee PK. Rapid validated HPTLC method for estimation of betulinic acid in Nelumbo nucifera (Nymphaeaceae) rhizome extract. Phytochem Anal. 2010; 21(6): 556-60. [CrossRef]

[31] Yuwono M, Indrayanto G. Validation of chromatographic methods of analysis. In: Brittain HG (ed). Profiles of Drug Substances, Excipients and Related Methodology. Academic Press, London, 2005, pp. 243-259. [CrossRef]

[32] Pandey H, Pandey P, Singh S, Gupta R, Banerjee S. Production of anti-cancer triterpene (betulinic acid) from callus cultures of different Ocimum species and its elicitation. Protoplasma. 2015; 252(2): 647-655. [CrossRef]

[33] Fresney, R.I, Culture of Animal Cells: A Manual of Basic Technique and Specialized Applications, John Wiley and Sons, New Jersey, USA 2010.

This is an open access article which is publicly available on our journal's website under Institutional Repository at http://dspace.marmara.edu.tr. 